\title{
New species of the catfish genus Tatia (Siluriformes:Auchenipteridae) from the rio Teles Pires, upper rio Tapajós basin, Brazil
}

\author{
Richard P. Vari ${ }^{1}$ and Bárbara B. Calegari²
}

Analysis of specimens of the auchenipterid catfish genus Tatia collected in the rio Teles Pires, a tributary of the rio Tapajós, along the border between the states of Pará and Mato Grosso, Brazil, revealed it to be an undescribed species. This new species is distinguished from all congeners with the exception of T. carolae and T. musaica by the intense, clearly demarcated, dark coloration on the dorsal and to varying degrees lateral and sometimes ventrolateral portions of the body versus the very lightly colored regions which are translucent in life on the remainder of the body. Various details of head, body and dorsal and caudal-fin pigmentation along with meristic and morphometric features distinguish the new species from $T$. carolae and T. musaica. The new species provides further evidence that the upper and middle rio Tapajós is a region of ichthyofaunal endemism.

A análise de espécimes do bagre auquenipterídeo do gênero Tatia, provenientes do rio Teles Pires, um tributário do rio Tapajós, na divisa entre os estados do Pará e Mato Grosso, Brasil, revelou se tratar de uma espécie ainda não descrita. Esta espécie nova distingue-se de seus congêneres, com exceção de T. carolae e T. musaica, por sua intensa e distintamente demarcada, coloração escura sobre o dorso a variados graus na porção lateral e algumas vezes ventro-lateral do corpo em contraste com regiões de coloração muito clara, a qual é translúcida em vida, no restante do corpo. Vários detalhes da pigmentação da cabeça, corpo, e nadadeira caudal e dorsal juntamente com características merísticas e morfométricas distinguem a espécie nova de T. carolae e T. musaica. A espécie nova fornece evidência adicional de que a porção alta e média da bacia do rio Tapajós é uma região de endemismo da ictiofauna.

Key words: Amazon basin, Centromochlinae, Endemism, Neotropical region, Taxonomy.

\section{Introduction}

Tatia Miranda Ribeiro is a genus of auchenipterid catfishes of small body sizes distributed across much of the expanse of South America east of the Andean Cordilleras from the río Orinoco south to the río de la Plata basin. In their analyses of Tatia, Soares-Porto (1998) and SarmentoSoares \& Martins-Pinheiro (2008) recognized 12 valid species in the genus. Sarmento-Soares \& Martins-Pinheiro (2008) additionally modified the limits of Tatia by shifting two species previously assigned to the genus, T. musaica and T. simplex, to incertae sedis status in the Centromochlinae. Soon thereafter, Pavanelli \& Bifi (2009) described an additional species of Tatia from the rio Paraná basin, and most recently Vari \& Ferraris (2013) added two new species of the genus from locations on the Guiana Shield in the Essequibo
River and río Orinoco basins. Vari \& Ferraris (2013) also made the case for the return of T. musaica to that genus. Analysis of specimens of Tatia from the rio Teles Pires in the upper reaches of the rio Tapajós, a southern tributary of the Amazon basin, revealed that they represent an undescribed species of the genus that is described herein.

\section{Material and Methods}

Counts and measurements follow Sarmento-Soares \& Martins-Pinheiro (2008), with the addition of the pelvic-fin to anal-fin distance (measured from the pelvic-fin origin to the anal-fin origin), the postdorsal length (measured from the end of the dorsal-fin base to the end of the caudal-fin peduncle), the caudal-peduncle width (measured at the same point as the minimum caudal-peduncle depth), the head depth

${ }^{1}$ Department of Vertebrate Zoology, National Museum of Natural History, Smithsonian Institution, Washington, D.C., 20560 USA. varir@si.edu

${ }^{2}$ Laboratório de Sistemática de Vertebrados, Pontifícia Universidade Católica do Rio Grande do Sul. Av. Ipiranga, 6681, P. O. Box 1429, 90619-900 Porto Alegre, RS, Brazil. barbara.calegari@gmail.com 
(measured at the posterior margin of the supraoccipital) and the prenasal length (measured from the snout tip to the anterior margin of the anterior naris). The count of vertebrae includes the terminal element associated with the hypural complex. This count assumes that the fifth vertebra, which lacks articulated ribs, is suturally united to the anterior four elements incorporated into the Weberian Complex and treats the first rib-bearing centrum as the sixth vertebra (Ferraris $\&$ Vari, 1999). Vertebral and unpaired fin ray counts along with details of dorsal- and pectoral-fin spine serrations were taken from radiographs. Measurements were made point-topoint and recorded to $0.1 \mathrm{~mm}$. Royero (1992), SarmentoSoares \& Martins-Pinheiro (2008), Pavanelli \& Bifi (2009), and Vari \& Ferraris (2013) served, in part, as the source of the comparative information used in the species diagnoses. Abbreviations used in text are: HL - head length and SL - standard length. Museum abbreviations are: AMNH American Museum of Natural History, New York; ANSP - The Academy of Natural Sciences, Philadelphia; CSBD - Centre for the Study of Biological Diversity, University of Guyana, Georgetown; INPA - Instituto Nacional de Pesquisas da Amazônia, Manaus; LACM - Los Angeles County Museum, Los Angeles; LBP - Laboratório de Biologia e Genética de Peixes, Universidade Estadual Paulista "Júlio de Mesquita Filho", Botucatu; MBUCV - Museu de Biologia, Universidad Central de Venezuela, Caracas; MCP - Museu de Ciências e Tecnologia, Pontifícia Universidade Católica do Rio Grande do Sul, Porto Alegre; MNRJ - Museu Nacional, Universidade Federal do Rio de Janeiro, Rio de Janeiro; MZUEL - Museu de Zoologia da Universidade Estadual de Londrina, Londrina; MZUSP - Museu de Zoologia da Universidade de São Paulo, São Paulo; ROM - Royal Ontario Museum, Toronto; SU (CASSU) - Stanford University collections now at CAS; UFRO - Universidade Federal de Rondônia, Porto Velho; and USNM - National Museum of Natural History, Smithsonian Institution, Washington, D.C.

\section{Results \\ Tatia melanoleuca new species}

Figs. 1-3

Holotype. MZUSP 114670, $32.4 \mathrm{~mm}$ SL, Brazil, along border between Pará and Mato Grosso states, Jacareacanga, close to Sete Quedas rapids, rio Teles Pires, tributary to upper rio Tapajós basin, 9²0’38"S 5646’42"W, 6 Oct 2008, L. M. Sousa \& A. L. Netto-Ferreira.

Paratypes. MZUSP 99944, 2, 21.7-24.6 mm SL; collected with holotype.

Diagnosis. Tatia melanoleuca can be readily distinguished from all congeners other than T. carolae and T. musaica by the strongly contrasting, dark coloration on the dorsal and to varying degrees lateral and ventrolateral portions of the body that is distinctly demarcated from the lightly colored regions that are translucent in life on the remainder of the body ( $v s$. a variety of alternative coloration patterns in congeners, none of which is comparable to this pigmentation pattern; see illustrations in Royero, 1992: fig. 1; Sarmento-Soares \& Martins-Pinheiro, 2008; Pavanelli \& Bifi, 2009: fig. 1; Vari \& Ferraris, 2013: figs. 1-2). Tatia melanoleuca is distinguished from T. musaica and T. carolae by the absence of dark pigmentation on the lower lobe of the caudal fin ( $v s$. a bilobed pattern of dark pigmentation in that region in $T$. carolae, or an extension of the dark body pigmentation onto the basal portions of the lobe in T. musaica) and the possession of 34 vertebrae (vs. 35 or 36 in T. carolae and 35 in T. musaica). Tatia melanoleuca additionally differs from $T$. carolae in the dark pigmentation that is uniformly continuous across the portion of the lateral line on the caudal peduncle (vs. with the area bordering the lateral line unpigmented and forming distinct, narrow, posteriorly dorsally angling white stripe within the dark pigmentation on the caudal peduncle), the lack of dark pigmentation on the upper lobe of the caudal fin or with such pigmentation barely extending onto the lobe ( $v s$. a bilobed pattern of dark pigmentation extending onto the lobe in that region), the narrower interorbital width $(42.0-42.9 \%$ vs. $51.8-62.4 \%$ HL), shallower snout depth (34.5-38.5\% vs. 43.4-47.5\% HL), shorter posterior internarial distance $(26.0-29.8 \%$ vs. $33.7-38.8 \%$ HL) and shorter caudal-peduncle length $(18.8-19.5 \%$ vs. 22.5 $25.3 \%$ SL). Tatia melanoleuca is further distinguished from T. musaica in the presence of an unpigmented region anterodorsal of the orbits either in the form of a rounded spot or a broad median band extending anteriorly to the upper lip (vs. with solid dark pigmentation in that region), the unpigmented dorsal-fin spine (vs. a dusky spine), the lack of dark pigmentation on the dorsal surface of the pectoral-fin spine other than basally (vs. dusky pigmentation extending at least one-half the length of the spine), the location of dark pigmentation on the body other than on the caudal-peduncle dorsal to the horizontal through the middle of the orbit (vs. dark pigmentation broadly extending ventral of that line and reaching to the ventral midline anterior to the anal-fin base), the deeper overall body as reflected in the greatest body depth (23.4-25.6\% vs.17.9-21.8\% SL) and deeper caudalpeduncle depth (13.9-14.5\% vs.9.6-12.0\% SL).

Description. Morphometric data presented in Table 1. Body depth approximately constant between dorsal- and analfin origins and slightly less than HL. Body approximately cylindrical from rear of head through abdomen and increasingly compressed towards caudal fin. Body width greatest at pectoral-fin origin; width slightly less than body depth at that point and tapering progressively towards caudal peduncle. Lateral line midlateral, complete and extending onto, and curving dorsally on caudal peduncle but falling short of posterior limit of hypural plate. Anus situated slightly anterior of anal-fin base. Vertebrae $34(n=2)$. Ribs $8(\mathrm{n}=2)$. 


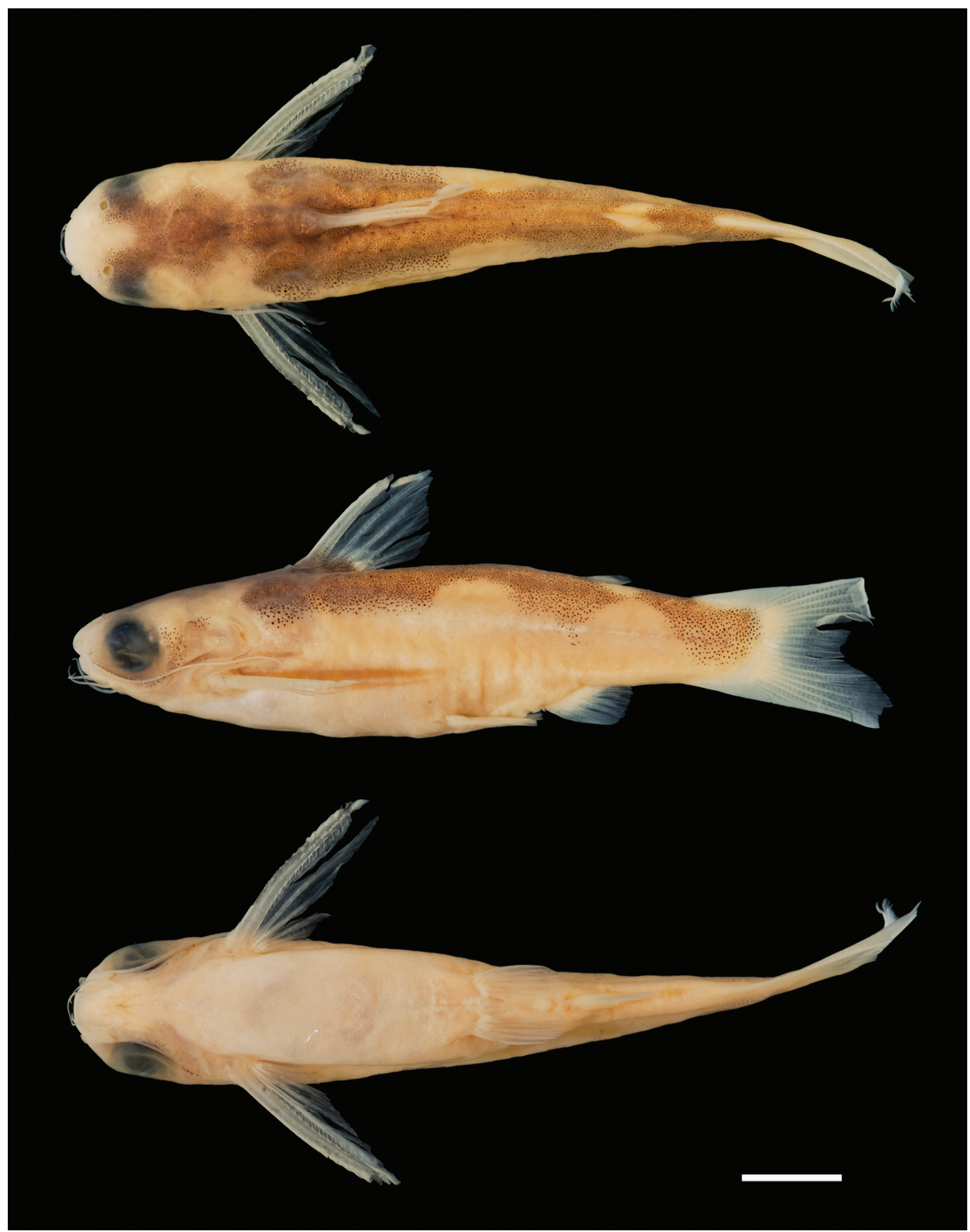

Fig. 1. Tatia melanoleuca, new species, MZUSP 114670, holotype, female, $32.4 \mathrm{~mm}$ SL, Brazil, along border between Pará and Mato Grosso states, Jacareacanga, rio Teles Pires, close to Sete Quedas, upper rio Tapajós basin; dorsal, lateral and ventral views. Scale bar $=0.5 \mathrm{~cm}$. 
Table 1. Morphometric data for Tatia melanoleuca . Hol.=holotype; range includes holotype and one paratype. SD= standard deviation.

\begin{tabular}{|c|c|c|c|c|c|}
\hline & Hol. & Low & High & Mean & $\mathrm{SD}$ \\
\hline Standard length $(\mathrm{mm})$ & 32.4 & 21.7 & 32.4 & 27.0 & - \\
\hline \multicolumn{6}{|l|}{ Percents of standard length } \\
\hline Body depth at anterior nuchal plate & 23.4 & 23.4 & 25.6 & 24.5 & 1.5 \\
\hline Body width at cleithrum & 22.0 & 22.0 & 24.3 & 23.1 & 1.7 \\
\hline Caudal-peduncle depth & 13.9 & 13.9 & 14.5 & 14.2 & 0.4 \\
\hline Caudal-peduncle length & 19.5 & 18.8 & 19.5 & 19.2 & 0.5 \\
\hline Caudal-peduncle width & 6.0 & 5.8 & 6.0 & 5.9 & 0.1 \\
\hline Predorsal length & 36.2 & 36.2 & 38.9 & 37.5 & 1.9 \\
\hline Postdorsal length & 55.3 & 51.9 & 55.3 & 53.6 & 2.4 \\
\hline Preanal length & 73.7 & 73.7 & 78.7 & 76.2 & 3.5 \\
\hline Prepelvic length & 58.9 & 58.9 & 64.8 & 61.8 & 4.1 \\
\hline Dorsal-fin to pectoral-fin distance & 22.7 & 22.7 & 26.9 & 24.8 & 3.0 \\
\hline Dorsal-fin to pelvic-fin distance & 34.9 & 34.9 & 36.7 & 35.8 & 1.3 \\
\hline Pectoral-fin to pelvic-fin distance & 38.0 & 38.0 & 40.5 & 39.2 & 1.8 \\
\hline Pelvic-fin to anal-fin distance & 16.1 & 15.7 & 16.1 & 15.9 & 0.3 \\
\hline Prepectoral length & 25.3 & 25.3 & 27.3 & 26.3 & 1.4 \\
\hline Dorsal-fin base length & 12.9 & 12.9 & 13.4 & 13.1 & 0.3 \\
\hline Adipose-fin base length & 5.2 & 5.2 & 5.7 & 5.4 & 0.4 \\
\hline Anal-fin base length & 9.1 & 9.1 & 9.8 & 9.4 & 0.5 \\
\hline Dorsal-fin spine length & 22.3 & 20.4 & 22.3 & 21.4 & 1.3 \\
\hline Pectoral-fin spine length & 28.6 & 28.4 & 28.6 & 28.5 & 0.1 \\
\hline Postcleithral process length & 19.6 & 19.6 & 22.1 & 20.8 & 1.8 \\
\hline First branched pelvic-fin ray length & 13.3 & 12.0 & 13.3 & 12.7 & 1.0 \\
\hline Longest anal-fin ray length & 12.7 & 12.7 & 13.0 & 12.9 & 0.2 \\
\hline Maxillary barbel length & 34.0 & 34.0 & 40.7 & 37.3 & 4.8 \\
\hline Lateral mental-barbel length & 9.1 & 9.1 & 10.6 & 9.9 & 1.0 \\
\hline Medial mental-barbel length & 6.3 & 6.3 & 6.8 & 6.5 & 0.3 \\
\hline Head length & 31.6 & 31.6 & 32.4 & 32.0 & 0.6 \\
\hline \multicolumn{6}{|l|}{ Percents of head length } \\
\hline Head depth & 66.4 & 66.4 & 69.5 & 67.9 & 2.2 \\
\hline Head width & 68.8 & 68.8 & 72.4 & 70.6 & 2.5 \\
\hline Snout depth & 34.5 & 34.5 & 38.5 & 36.5 & 2.8 \\
\hline Interorbital distance & 42.0 & 42.0 & 42.9 & 42.4 & 0.6 \\
\hline Anterior-posterior nareal width & 14.3 & 11.8 & 14.3 & 13.0 & 1.7 \\
\hline Anterior internarial distance & 26.6 & 23.2 & 26.6 & 24.9 & 2.4 \\
\hline Posterior internarial distance & 26.0 & 26.0 & 29.8 & 27.9 & 2.7 \\
\hline Snout length & 31.5 & 31.5 & 31.8 & 31.7 & 0.2 \\
\hline Orbital diameter & 30.2 & 30.2 & 30.5 & 30.4 & 0.3 \\
\hline Mouth width & 30.1 & 30.1 & 33.4 & 31.7 & 2.3 \\
\hline Prenasal length & 11.9 & 10.7 & 11.9 & 11.3 & 0.9 \\
\hline
\end{tabular}

Head slightly depressed and tapering anteriorly. Maximum head width at transverse through opercular hinge; width at hinge approximately equal to maximum head depth but less than maximum body depth. Head profile very gently convex both dorsally and ventrally in lateral view. Head and snout broadly rounded in dorsal view. Opercular margin wide and attached to isthmus. Mouth terminal with opening situated slightly ventral to horizontal through middle of snout. Eye large, midlateral and centered at middle of head depth. Eye prominent in ventral view of head, but somewhat less obvious from dorsal view. Anterior naris located slightly posterior to margin of snout and surrounded by short, anteriorly directed tube. Posterior naris remote from anterior naris; situated anterodorsal to orbit and along vertical through anterior margin of orbit. Posterior naris with very short, fleshy flap anteriorly. No barbel associated with naris. Maxillary barbel long, slender, and extending to vertical through anterior one-third of dorsal-fin base. Lateral mental barbel somewhat longer than medial mental barbel and extending posteriorly slightly beyond vertical through posterior margin of eye.

Dorsal-fin rays II,5. Dorsal-fin height slightly greater than body depth at dorsal-fin origin. Tip of adpressed dorsal fin extends beyond vertical through pelvic-fin origin. First 
branched dorsal-fin ray slightly longer than dorsal-fin spine; remaining fin-rays progressively decreasing in length posteriorly with overall fin margin concave. Last fin-ray without posterior membranous attachment to body. Dorsal-fin spine stout; bearing slender, widely spaced serrations along distal half of anterior margin. Most of serrations aligned at right angles relative to axis of dorsal spine, but more distally directed near tip of spine. Serrations less obvious in smaller individuals. Serrations along distal portion of posterior margin of spine similar in size and spacing to those along anterior margin, but limited to 2 or 3 serrations along distal portion of spine. Adipose fin small; rounded dorsally in lateral profile. Adipose-fin origin situated slightly anterior of vertical through posterior limit of anal-fin base.

Anal-fin rays iii,7. Anal-fin origin situated posterior of vertical through tip of pelvic fin. Tip of adpressed anal fin falling distinctly short of anterior most procurrent caudalfin rays. Base short and largely located anterior to vertical through adipose-fin origin. Fin margin slightly convex with anterior and posterior rays slightly longer. Last fin-ray lacking membranous attachment to body.

Principal caudal-fin rays i,7,8,i. Caudal fin moderately forked, symmetrical; lobes somewhat pointed to rounded. Length of middle caudal-fin rays more than one-half length of longest rays. Procurrent rays dorsally and ventrally symmetrical; anterior most rays originate posterior of middle of caudal peduncle and gradually increase in length posteriorly.

Pectoral-fin rays I,5. Pectoral fin long, slender. Tip of adpressed fin extends slightly beyond vertical through posterior terminus of dorsal-fin base but falls well short of pelvic-fin origin. Pectoral-fin spine long with serrations along distal one-half of anterior margin. Serrations along anterior margin of spine aligned at right angles to axis of spine for slightly over basal one-half of serrated region; serrae becoming increasingly stout and antrorse along distal portion of serrate region. Retrorse serrations present along posterior two-thirds of spine margin; both size of, and spacing between, spines increasing distally. Spines on basal portion of anterior margin of spine more slender than corresponding spines along posterior margin. Branched pectoral-fin rays, particularly medial most ray, becoming progressively shorter posteriorly.

Pelvic-fin rays i,5. Pelvic fin with rounded distal margin; second and third branched rays longest. Pelvic-fin origin located slightly anterior to vertical through tip of adpressed dorsal fin. Fin margin falling slightly short of anal-fin origin.

Color in alcohol. Dark pigmentation on dorsal and dorsolateral portions and to varying degrees lateral and sometimes ventrolateral portions of posterior region of body delimited along distinct margin from unpigmented, very lightly colored remaining regions of body (Fig. 1). Dark pigmentation largely situated dorsal of horizontal through middle of orbit; extending slightly further ventrally overall in smaller examined specimens and reaching to ventral midline of posterior portion of caudal peduncle versus only twothirds of distance to that point in largest specimen (holotype). Vertically elongate, tear-drop shaped unpigmented area present posteroventral to base of dorsal-fin spine in smaller specimens; that region uniformly dark in larger holotype. Dark pigmentation on caudal peduncle continuous across posterior portion of lateral line and terminating at base of caudal-fin rays or barely extending onto base of few central rays of upper lobe.

Dark pigmentation on dorsal surface of head in largest specimen (holotype) with rounded area of dark pigmentation joined by less intense coloration posteriorly to dark pigmentation of dorsal portion of body. Rounded area of dark pigmentation on dorsal surface of head continuous anteriorly with anterolaterally directed, broad band of dark pigmentation extending forward on each side to barely surround each posterior nostril. Contralateral anterolaterally directed bands jointly form V-shaped pattern with base pointed posteriorly. Dark pigmentation on dorsal surface of head in smaller specimens more extensive than in holotype and seamlessly continuous posteriorly with dark pigmentation of dorsal portion of body. Smaller individuals with dark pigmentation of dorsal region of head continuing anteriorly to beyond posterior nostril, but with slightly longitudinally elongate, ovoid, unpigmented area middorsally in region between anterior portions of orbits. Scattered concentrations of groups of dark chromatophores forming irregularly shaped spots posterior to orbit and on opercle in specimens of all sizes; spots more obvious in largest individual (holotype). Ventral surface of head unpigmented. Basal portion of maxillary barbel with dorsal series of dark chromatophores. Remainder of maxillary barbel as well as both mental barbels lacking dark pigmentation.

Dorsal fin with concentration of dark chromatophores covering base of spines and two anterior branched rays; remainder of fin unpigmented. Adipose fin unpigmented. Pectoral-fin spine with few scattered dark chromatophores on medial most portion of dorsal surface. Remainder of spine and all fin-rays otherwise unpigmented. Pelvic and fins hyaline. Dark pigmentation of caudal peduncle extends very short distance onto basal portion of dorsal lobe of caudal fin in some individuals. Remainder of fin hyaline.

Color in life. Overall coloration pattern of strongly contrasting dark and light coloration as in preserved specimens, but with dark pigmentation more intense. Regions of head and body lacking dark pigmentation somewhat translucent. Slight bluish tint on lateral surfaces of body. Dorsal and lateral surfaces of head with distinctive lightly colored to translucent areas on dorsal portion of the snout, posterior nuchal plate region, and posterodorsal to orbit. Region posterior to orbit with evident oval black surface blotch. All fins hyaline. (Description based on photographs by Heriberto Gimenes Junior of specimens captured October 2013 in the rio Jamanxim, Fig. 2). 


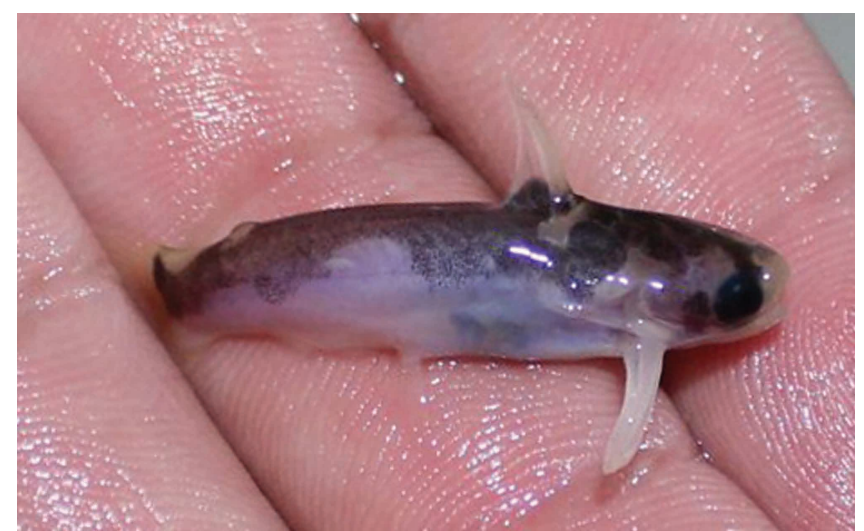

Fig. 2. Life coloration of specimen of Tatia melanoleuca collected in rio Jamanxim, tributary to upper rio Tapajós basin. Photograph courtesy of Heriberto Gimenes Junior.

Distribution. Examined specimens of Tatia melanoleuca all originated from the rio Teles Pires in the rio Tapajós catchment in the southern portion of the Amazon basin (Fig. 3 ). Photographed (but not vouchered) evidently conspecific specimens originated in the rio Jamanxim (see Color in Life above), a right bank tributary of the rio Tapajós immediately north of the rio Teles Pires.

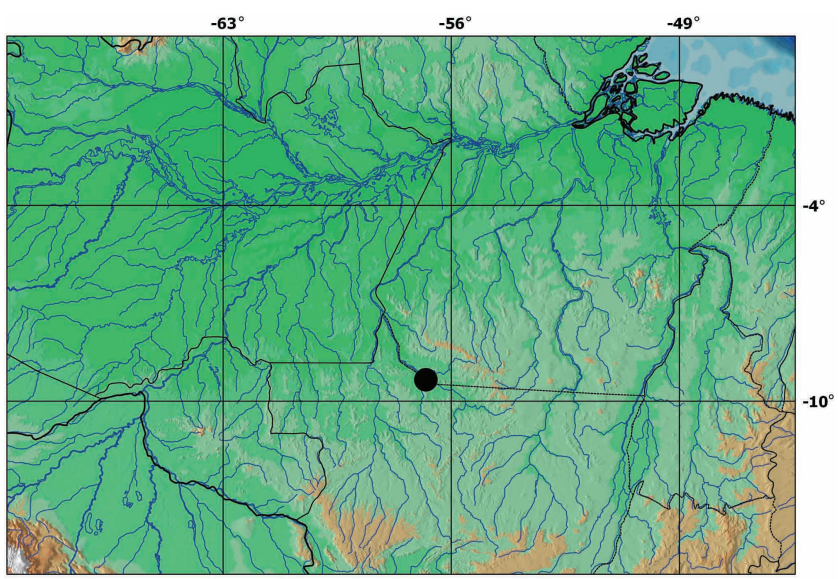

Fig. 3. Map of southeastern Amazon basin showing location of type locality of Tatia melanoleuca.

Ecological notes. A population of Tatia melanoleuca collected in the rio Jamanxim by H. G. Junior inhabited a $2 \mathrm{~m}$ deep stretch of the river characterized by clear water and somewhat lentic to slow flowing waters. The substrate in the sampled area consisted primarily of sand and rocks with some submerged tree trunks. Tatia melanoleuca was collected near the river margin at twilight while searching for food on the water surface. This activity period and feeding behavior is typical across the Centromochlinae.

Etymology. The species epithet, melanoleuca, is from the Greek melano, meaning black, and leukos, meaning white, in allusion to its black-and-white color pattern. An adjective.

\section{Discussion}

Tatia melanoleuca shares one of the external features advanced by Sarmento-Soares \& Martins-Pinheiro (2008) as defining Tatia: the compressed, deep caudal peduncle with a middorsal keel posterior to the adipose fin. The second of the features proposed by those authors - the reduction in the length of the anal-fin base of adult males - could not be evaluated in the absence of mature males. The third feature proposed by those authors for Tatia - the anterodorsally elongate hyomandibula not contacting the narrow metapterygoid was not apparent in radiographs and the limited available material of the species did not permit the preparation of a cleared and stained osteological specimen that would allow us to determine the form of that bone. Evidence from the caudal peduncle form, nonetheless, justifies the placement of the new species in Tatia. Furthermore, T. melanoleuca lacks the elongated maxilla, which is diagnostic for Centromochlus (Sarmento-Soares et al., 2013), the centromochlin genus most similar to Tatia.

Lack of a proposed phylogeny for the species of Tatia renders it impossible to critically evaluate the closest relatives of T. melanoleuca. Notwithstanding this limitation, it is noteworthy that the new species is most similar externally to T. musaica and T. carolae. Exemplifying this similarity is the very distinctive contrasting dark versus very light pigmentation pattern on the body that is unique to these three species within the genus. Tatia melanoleuca is known from rio Tapajós basin which drains a portion of the Brazilian Shield whereas T. musaica and T. carolae occur on two different regions of the Guiana Shield. Further analysis is necessary to test a close relationship between T. melanoleuca, T. musaica, and T. carolae, but such a relationship would conform to the pattern noted by Lima \& Ribeiro (2011) of sister-group relationships between fish species occurring on shield areas in the Amazon basin and species inhabiting shield-draining rivers in the río Orinoco basin and the Guianas.

The samples that served as the basis of the description of Tatia melanoleuca originated in the upper rio Tapajós basin, which as defined by Britski \& Lima (2008) is the portion of that catchment upstream from the confluence of the rio Juruena and rio Teles Pires. The upper and middle portions of rio Tapajós drainage are characterized by many rapids along the main course of the river and its tributaries, with the first major cataracts located near Itaituba downstream of the mouth of the rio Jamanxim and approximately $200 \mathrm{~km}$ from mouth of the Tapajós in the mainstream Amazon (Goulding et al., 2003: fig. 2.13; Albert et al., 2011). In so far as waterfalls are potential barriers to fish dispersal (Goulding et al., 2003; Britski \& Lima, 2008), these cataracts may be a contributing factor in the notable level of species endemism among the fishes inhabiting upper and middle portions of the rio Tapajós basin.

Although the ichthyofauna of the upper rio Tapajós was historically poorly known, the increasing sampling in 
that region during recent years yielded multiple previously unknown fish species apparently endemic to that basin. These species belong primarily to the Characiformes (Caenotropus schizodon Scharcansky \& Lucena, 2007; Hasemania kalunga Bertaco \& Carvalho, 2010; Hyphessobrycon kayabi Teixeira, Lima \& Zuanon, 2013; Hyphessobrycon melanostichos Carvalho \& Bertaco, 2006; Hyphessobrycon notidanos Carvalho \& Bertaco, 2006; Hyphessobrycon peugeoti Ingenito, Lima \& Buckup 2013; Jupiaba iasy Netto-Ferreira, Zanata, Birindelli \& Sousa, 2009; Leporinus britskii Feitosa et al., 2011; Moenkhausia cosmops Lima et al., 2007; Moenkhausia plumbea Sousa, Netto-Ferreira \& Birindelli, 2010), with a lesser number of members of the Cichlidae (Crenicichla chicha Varella, Kullander \& Lima, 2012) and Siluriformes (Centromochlus meridionalis Sarmento-Soares, Cabeceira, Carvalho, Zuanon \& Akama, 2013; Hassar shewellkeimi Sabaj-Pérez \& Birindelli, 2013; Hisonotus chromodontus Britski \& Garavello, 2007; H. luteofrenatus Britski \& Garavello, 2007; Corydoras apiaka Espíndola, Spencer, Rocha \& Britto, 2014). Tatia melanoleuca is yet another previously undescribed siluriform from the area and studies revealed a species of Gelanoglanis previously unknown to science in that basin. Further analyses of the ichthyofauna of the rio Tapajós basin and adjoining basins are necessary to determine the degree to which this apparent endemicity of the ichthyofauna in the upper portion of the rio Tapajós is an actuality rather than an artifact of inadequate sampling in that region.

A notable aspect of the known distribution of Tatia melanoleuca is its apparently disjunct distribution in the adjoining rio Teles Pires (type locality) and rio Jamanxim basins (latter report based on photographs). Occurrence of T. melanoleuca in these river systems is a possible consequence of transfer between headwater portions of those adjacent basins during geological shifts in the area of Serra do Cachimbo. Regardless of the underlying cause, the distribution of T. melanoleuca is evidence of some level of ichthyofaunal similarity between the Jamanxim drainage and the upper portion of Tapajós basin (e.g., rio Teles Pires). Additional studies are necessary to evaluate the hydrographic boundaries that may delimit an area of ichthyological endemism in these basins and to resolve the distribution of this new species.

Comparative material examined. Centromochlus altae: Peru: LACM 41729-42, 19 (1 c\&s), Amazonas, río Santiago at La Poza. Centromochlus existimatus: Brazil: MCP 29838, 2 (1 c\&s), Amazonas, Alvarões, lago Mamirauá. Centromochlus heckelii: Brazil: MCP 17452, 10 (1 c\&s), Amazonas, Itacoatiara, rio Amazonas at Itacoatiara harbor. Centromochlus macracanthus: Brazil: MZUSP 92986, 50 (1 c\&s), Amazonas, rio Tiquié, between São José and Bela Vista. Centromochlus meridionalis: Brazil: MCP 32975, 6 paratypes, Mato Grosso, Ribeirão Macuco at road BR-163 approximately $74 \mathrm{~km}$ north of Sinop, tributary to rio Tapajós basin. Centromochlus perugiae: Ecuador: USNM 167912, 2 (1 c\&s), pool near mouth of río Pucuno; Peru:
MCP 45749, 5 (1 c\&s), Ucayali, Pucallpa, laguna Yarinacocha. Centromochlus punctatus: Venezuela: LACM 43354-40, 4 (1 c\&s), Delta Amacuro, río Orocopiche, ca. $15 \mathrm{~km}$ from mouth in río Orinoco, downstream from route 19. Centromochlus romani: Venezuela: USNM 258227, 16 (1 c\&s), Guarico, río Orituco where crossed by road from Calabozo. Centromochlus schultzi: Brazil: MZUSP 94138, 7 (1 c\&s), Mato Grosso, Gaúcha do Norte, rio Culuene, at Sr. Zezé farm. Tatia aulopygia: Brazil: UFRO 3170, 1, Rondônia, Porto Velho, mouth of rio Jaciparaná, tributary to rio Madeira basin. Tatia boemia: Brazil: MCP 44263, 6 (1 c\&s), Rio Grande do Sul, Nonoai, rio Passo Fundo, at Monjolinho hydroeletric plant. Tatia brunnea: Brazil: INPA 29616, 1, Pará, Porto Trombetas, creek Saracá plateau, tributary to rio Trombetas; INPA 29988, 3 of 7, Amazonas, Manaus, Cabo Frio, Rio Preto da Eva, tributary to rio Negro; MZUSP 84977, 35 (1 c\&s), Amazonas, rio Tiquié, between cachoeira da Pedra Curta and São Pedro. Tatia carolae: Guyana: USNM 401514, holotype, Cuyuni-Mazaruni, Cuyuni River, sand island in middle of river just downstream from Kurutuku; USNM 408386, paratype, collected with holotype; USNM 401511, paratype, CuyuniMazaruni, Cuyuni River, sand and gravel beaches downstream from rapids at Kanaima Falls. Tatia caxiuanensis: Brazil: MNRJ 12134, 8, Amapá, rio Aporema, tributary to rio Araguari, at Modelo Aporema farm. Tatia galaxias: Venezuela: SU 53627, 17 (2 c\&s), Bolivar, caño de Quiribana near Caicara; ANSP 180821, 5, Bolivar, Ciudad Bolivar highway, río Caura at ferry crossing (E side) at Caicara. Tatia gyrina: Brazil: MCP 36339, 8 (1 c\&s), Rondônia, Porto Velho, creek Taquarás on BR-425, near GuajaráMirim; MCP 46589, 2 (1 c\&s), Roraima, Santa Maria do Baiaçu, Igarapé Cambeua, tributary to rio Jauaperi. Tatia intermedia: Guyana, Essequibo: ROM 84053, 1, Cuyuni River approximately $0.5 \mathrm{mi}$ from mouth, tributary to Mazaruni River; ROM 86248, 3, Potarinao, Takutu River at road crossing, Rio Branco, Amazon basin; Brazil: MCP 29852, 2 (1 c\&s), Amazonas, Alvarões, lago Jaraqui, rio Jarauá system. Tatia jacaratia: Brazil: MZUSP 109792, 11 (1 c\&s), Paraná, Capanema, rio Iguaçu, Parque Nacional do Iguaçu. Tatia marthae: Venezuela: ANSP 146201, holotype, Bolivar, cãno Cuchima of río Cusimi, approximately 20 mi upstream from junction of río Erebato at Entre Ríos; ANSP 199070, paratype, collected with holotype. Tatia meesi: Guyana: MZUSP 109086, 18 (1 c\&s), Potaro-Siparuni, Kuribrong River. Tatia musaica: Venezuela: MBUCV V-15663, holotype (photograph only); AMNH 58495, paratype, 1 of 3, Amazonas, San Fernando de Atabapo, río Atabapo ca. $3 \mathrm{~km}$ from its mouth in río Orinoco; ANSP 164979 (formerly MBUCV V-17727, in part), 2, paratypes, Amazonas, río Atabapo, approximately $3 \mathrm{~km}$ from its mouth, San Fernando de Atabapo; ANSP 160697, 1, Amazonas, río Sipapo, ca. $5 \mathrm{~km}$ upstream from Pendare; ANSP 199125, 6, Amazonas, San Fernando de Atabapo, río Atabapo, beaches at confluence with río Guaviare; ANSP 182970, 3, Amazonas, San Fernando de Atabapo, río Orinoco near confluence with río Atabapo, long narrow beach between channel and laguna. Tatia neivai: Brazil: MZUSP 109794, 11 (1 c\&s), Paraná, Capanema, rio Iguaçu, at Parque Nacional do Iguaçu. Tatia nigra: Brazil: MCP 46029, 7 (1 c\&s), Amazonas, Barcelos, Igarapé ApanhaLuz, $20 \mathrm{~km}$ downstream from Barcelos. Tatia simplex: Brazil: 
LBP 1647, 3, Mato Grosso, Araguaiana, córrego do Cândido, rio Araguaia. Tatia strigata: Venezuela: USNM 338006, 3 (1 c\&s), Amazonas, Departamento Río Negro, caño Tremblador where crossed by road from San Carlos to Solano, upstream portion; Brazil: MCP 46595, 3 (1 c\&s), Roraima, Santa Maria do Baiaçu, Igarapé Cambeua, rio Jauaperi.

\section{Acknowledgments}

We are grateful to Fernando Jerep (MZUEL) for suggestions as to the improvement of the paper; Heriberto Gimenes Junior for the photographs of live specimens and information about their habitat; Sandra Raredon (USNM) for the photographs of the holotype and assistance with radiography; Jeffrey Clayton (UNSM) for assistance; and to Scott Schaefer and Barbara Brown (AMNH), Mark Sabaj Pérez (ANSP), David Catania (CAS), Lúcia R. Py-Daniel (INPA), Christine Thacker and Rick Feeney (LACM), Claudio Oliveira (LBP), Carlos A. S. Lucena (MCP), Paulo Buckup and Marcelo Britto (MNRJ), Osvaldo Oyakawa, José Lima de Figueiredo, and Michel Gianeti (MZUSP), Hernán López-Férnandes (ROM), Willian Ohara, Luiz J. de Queiroz and Christian Cramer (UFRO) for the loan of specimens. Support for this project was provided by the Conselho Nacional de Desenvolvimento Científico e Tecnológico (CNPq, process \#140439/2011-0), the Coordenação de Aperfeiçoamento de Pessoal de Nível Superior (CAPES, process \#3918/13-0) which funded a visit to the Smithsonian Institution by BBC, and by the Herbert R. and Evelyn Axelrod Chair in Systematic Ichthyology in the Division of Fishes, National Museum of Natural History of the Smithsonian Institution to RPV.

\section{Literature Cited}

Albert, J. S., P. Petry \& R. E. Reis. 2011. Major biogeographic and phylogenetic patterns. Pp. 21-57. In: Albert, J. E. \& R. E. Reis (Eds.). Historical Biogeography of Neotropical Freshwater Fishes. Berkeley, University of California Press.
Britski, H. A. \& F. C. T. Lima. 2008. A new species of Hemigrammus from the upper rio Tapajós basin in Brazil (Teleostei: Characiformes: Characidae). Copeia, 2008: 565-569.

Ferraris Jr., C. J. \& R. P. Vari. 1999. The South American catfish genus Auchenipterus Valenciennes, 1840 (Ostariophysi: Siluriformes: Auchenipteridae): monophyly and relationships, with a revisionary study. Zoological Journal of the Linnean Society, 126: 387-450.

Goulding, M., R. Barthem \& E. Ferreira. 2003. The Smithsonian Atlas of the Amazon. Washington, Smithsonian Books.

Lima, F. C. T. \& A. C. Ribeiro. 2011. Continental-scale tectonic controls of biogeography and ecology. Pp. 145-164. In: Albert, J. E. \& R. E. Reis (Eds.). Historical Biogeography of Neotropical Freshwater Fishes. Berkeley, University of California Press.

Pavanelli, C. S. \& A. G. Bifi. 2009. A new Tatia (Ostariophysi: Siluriformes: Auchenipteridae) from the rio Iguaçu basin, Paraná State, Brazil. Neotropical Ichthyology, 7: 199-204.

Royero, R. 1992. Tatia musaica, una nueva especie de bagre auquenipterido (Siluriformes-Auchenipteridae) de la cuenca del Rio Orinoco, Territorio Federal Amazonas, Venezuela. Acta Científica Venezuelica, 43: 300-306.

Sarmento-Soares, L. M. \& R. F. Martins-Pinheiro. 2008. A systematic revision of Tatia (Siluriformes: Auchenipteridae: Centromochlinae). Neotropical Ichthyology, 6: 495-542.

Sarmento-Soares, L. M., F. G. Cabeceira, L. N. Carvalho, J. Zuanon \& A. Akama. 2013. Centromochlus meridionalis, a new catfish species from the southern Amazonian limits, Mato Grosso State, Brazil (Siluriformes: Auchenipteridae). Neotropical Ichthyology, 11: 797-808.

Soares-Porto, L. M. 1998. Monophyly and interrelationships of the Centromochlinae (Siluriformes: Auchenipteridae). Pp. 331350. In: Malabarba, L. R., R. E. Reis, R. P. Vari, Z. M. Lucena \& C. A. S. Lucena (Eds.). Porto Alegre, Edipucrs.

Vari, R. P. \& C. J. Ferraris Jr. 2013. Two new species of the catfish genus Tatia (Siluriformes: Auchenipteridae) from the Guiana Shield and a reevaluation of the limits of the genus. Copeia, 2013: 396-402. 